\title{
Life in"Downton": The Representation of Edwardian Social Hierarchies in Downton Abbey (2010)
}

\author{
$1^{\text {st }}$ Novia Magda Imanuella Tambunan \\ English Studies Program, Faculty of \\ Humanities \\ Universitas Indonesia, \\ Depok, Indonesia \\ novimanuell@gmail.com
}

\author{
$2^{\text {nd }}$ Junaidi \\ Linguistics Department, Faculty of \\ Humanities \\ Universitas Indonesia, \\ Depok, Indonesia \\ junaidi@ui.ac.id
}

\begin{abstract}
The Edwardian Era (1901-1914) represents a period of extreme socio-economic inequality in Britain. The upper-class invested its financial resources on land and built luxurious estates with large country houses; the lower-class struggled to survive. More than one million people in Edwardian England were compelled by survival needs to work as domestic servants for upper-middle-class and upper-class households. Besides the economic inequity, the period was also characterized by extreme gender inequality. For instance, women could not inherit property and female servants worked at significantly lower wages than male retainers. This study examines the TV series Downton Abbey (2010) to better understand how gender and social inequalities shaped Edwardian society. To this end, the paper presents a comprehensive analysis of the mise-en-scenes, characterization, architecture, and interior design of the English country houses depicted in the series. Thus, selected scenes are used as data and are scrutinized through the strategic concepts of front stage and backstage [1], cinematography and mise-en-scenes [2], and critical visual methodology [3]. The findings of this investigation indicate that Downton Abbey accurately represents the Edwardian social hierarchy by carefully utilizing the three mentioned strategies to portray gender and social inequalities.
\end{abstract}

Keywords-Downton Abbey, social hierarchy, social inequalities, gender inequalities, Edwardian era

\section{INTRODUCTION}

The Edwardian era (1901-1914) was a period of British History when the social hierarchy was defined by rigid rules of etiquette. The citizenry was required to be aware of its class position and to behave in a manner deemed appropriate for each rank. At the same time, the wealth distribution among social classes was immensely unequal in this period (Hynes, 1968). The upper echelons of society, including aristocrats, tended to purchase large swathes of land and build country houses using their inordinate wealth, while the lower classes were completely reliant on their affluent masters, serving them as farmers, factory workers, and most often, as domestic servants. Moreover, a person's gender also influenced social mobility in the Edwardian social hierarchy. Females were considered the weaker sex and were hence deemed less valuable than men. Edwardian women were required to hand over all their money and immovable property to their husbands because women were thought to "belong" to their men.
The first season of the British TV series, Downton Abbey (2010), explored the lives of an Edwardian aristocratic family along with its army of servants. It was set in a country house called "Downton." The divergent lifestyles of the masters and the servants who reside in Downton draw attention to two significant aspects of inequity presented by Edwardian society: gender and class. Some scholars have previously studied the gender and social inequalities in Edwardian England as depicted in Downton Abbey. Chaubel (2016) [4] reported on six seasons of Downton Abbey, focusing on the effectiveness of the characterization to illustrate the gender inequalities and class system that prevailed in Britain at the time, concluding that the series offers a realistic portrayal of the disparities that branded the era and that are aptly represented by the family and servants residing in the country manor. Helgadottir's [5] investigation also accomplished a similar analysis, albeit more historically inclined, on the manner in which the characters effectively illustrate the predominant social conditions of the Edwardian era. She concluded that the outcomes of World War I as depicted in Downton Abbey, did not completely eradicate the social injustices prevalent in English society; however, wartime conditions did help to narrow the gaps between the social classes. Further, Baena and Byker [6] evaluated the Englishness and the relevance of nostalgia in Downton Abbey through the characters, arguing that the series allows its audience to get a sense of the past, specifically with regard to the gender and social disproportions evident in the Edwardian era.

Although the abovementioned studies have already discussed the interactions between masters and servants in Downton Abbey and examined the ways in which the characters illustrate the actual conditions that prevailed in Edwardian society, some critical aspects remain understudied. None of the studies conducted thus far have discussed the ways in which cinematographic elements such as lighting, camera movement, and camera position assist the director to effectively represent social issues to the audience of Downton Abbey. Further, none of the extant studies have examined how the architecture and interior design of the fictitious manor called Downton emphasize the defining lines between "the rich" and "the poor," and also illuminate the boundaries drawn between men and women. The present study endeavors to fill this research gap, and purposes to scrutinize not just the characters of Downton Abbey, but also its mise-en-scenes, and the architecture and interior design of the house after which the series is named. The data for this 
study comprise selected scenes from Season 1 of Downton Abbey, directed by Jullian Fellowes. The current investigation examines the Edwardian social hierarchy as depicted in the TV series and discusses its representations of gender and social inequalities. The paper is divided into three segments: the cinematographic elements and the mise-enscenes or the what and how of filming, which the director uses as a strategy to deliver messages to the audience; the characterization; and finally, the architecture and interior design of the primary set of the series, the English country manor.

\section{METHOD}

Critical Visual Methodology [3] is a method through which visual materials can be examined. This approach can help researchers understand the diverse range of methods that may be applied to visual communication. According to this framework, meaning is produced in four sites of visual media: image, circulation, audience, and production. Each site encompasses three modalities: technological, compositional, and social. The technological modality indicates how an image is made and displayed (Mirzoeff, 1999) [7]. The compositional modality represents the compositional elements of the visual image, such as correlations between the content and color of images. The social modality describes the interactions between the image and social, economic, or political realities. This article will focus only on the site of image. Considering the technological and compositional modalities of the component of image, this paper will delve into the mise-enscene elements of Downton Abbey and will analyze how these features are used by the director to depict social values and gender issues in the Edwardian era. With regard to the social modality of the images used, the paper will scrutinize the visual significations represented by the characters, and will also assess the architecture and interior design of Downton, the Edwardian country house that embodies the principal setting of Downton Abbey.

\section{RESULT AND DISCUSSION}

\section{A. Cinematography and Mise-en-scenes}

According to Broadwell and Thompson [2], the element of setting is more than a "container" for human events. Setting can also dynamically enter the narrative action as it can shape the audience's interpretation of the story. Highclere Castle in Hampshire, England, was used as the English country house setting by the director for this TV series representing the social stratification of the Edwardian era. Highclere Castle used to be the residence of George Herbert, the 8th Earl of Carnarvon. The director's selection of a real country manor as the setting for the series underscores the show's authenticity for the audience. Also, the actual filming of the series in a place once inhabited by both aristocrats and servants allows the audience to visualize and more tangibly appreciate the social hierarchy and the gender and social inequalities of the Edwardian era. Particular cinematographic elements and mise-en-scenes are utilized in Downton Abbey by the director to highlight the importance of English country houses as symbols of the upper-class identity and to emphasize the social chasm that divided the classes from the masses. During this period, the social standing and political power of the upper echelons of society were tethered to their country houses. Therefore, whatever the time of day, morning or night, the director was inclined to employ extreme long shots that would allow the audience to take in the entirety of the magnificent country house [2].

Camera movements and shots can also enhance perceived spatial information in images communicated to the audience [2]. The director used distinctive camera movements and shots to portray the various characters in the show. The camera is usually stable when it follows the members of the family. Conversely, numerous camera movements are used in scenes that portray servants. For instance, in every scene where servants are shown to be busy preparing breakfast for the family, the camera shifts rapidly to emphasize the hectic atmosphere of the servant's quarters (Figure 1). On the other hand, the camera remains relatively steady as the family enjoys its breakfast. Thus, the very movement of the cameras is intended to emphasize the servants' position as the working class and the family's position as the masters.

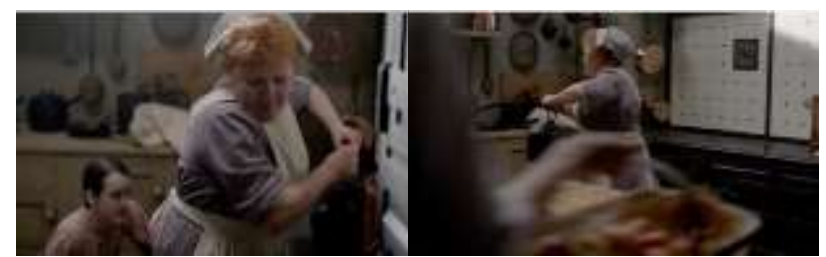

Fig. 1. Servants preparing breakfast (Downton Abbey Ep 1 00:02:20)

Additionally, lighting is a mise-en-scene element that aids in the overall atmosphere created by each shot. It also helps to guide the focus of the audience on certain objects [2]. Bright lighting is often used in scenes that take place in the masters' rooms; the audience is thus able to inspect the expensive trappings of these rooms. The camera rarely takes close-up shots when portraying characters who occupy the masters' rooms because the decor of these settings is considered an important indicator of the character's social status. To cite one example, the scene in which Lord Grantham and Lady Mary converse in the Great Library uses a long shot rather than a close-up frame that would show the facial expressions of the characters. This wider perspective allows the audience to clearly absorb the elegant decor and magnitude of the room [Figure 2 (left)]. Moreover, using high-key lighting in all breakfast scenes, the camera's position highlights the majestic paintings rather than the characters' faces [Figure 2 (right)].

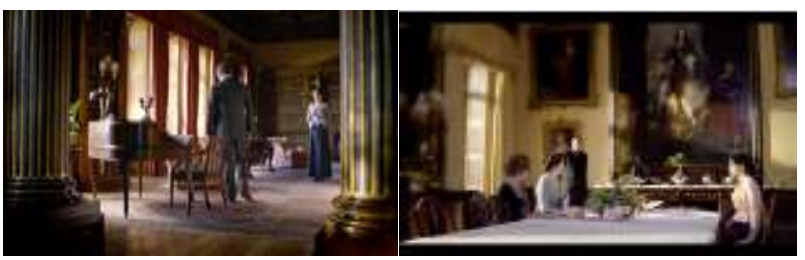

Fig. 2. Left figure: Lord Grantham and his daughter, Lady Mary, in Downton's library (Downton Abbey Ep 1 00:13:38). Right figure: The masters at the breakfast table (Downton Abbey Ep 1 00:08:35)

While the director favored the use of high-key lighting in scenes that were shot in the masters' rooms, a contrasting low-key lighting is instead used in scenes that are filmed in the servants' quarters [Figure 2 (right)]. The opposition of the social ranking of the haves and the have-nots is thus brought home: the servants are left unseen in the dark while the masters shine in the spotlight. The masters' rooms as 
oases of joy and leisure, spaces of beauty and majesty, while the servants' quarters are gloomy areas that are full of strife and bustle.

Further, the grand front door of the house is used only by the masters and their guests. Servants and other lower-class tradespeople must use the back door. This social distinction is illustrated in the second episode of Downton Abbey when one of the servants' guests tries to enter the house using the front door. An examination of this mise-en-scene reveals that the director uses a low angled shot for this scene [Figure 3 (right)]. This angle is deliberately used to make the door seem so immense it dwarfs the character, Mr. Carson's friend, in the frame. The poor and socially disadvantaged are powerless when confronted with majesty. They cannot get direct entry to the grand Downton, the symbol of Lord Grantham's aristocratic lineage [2].

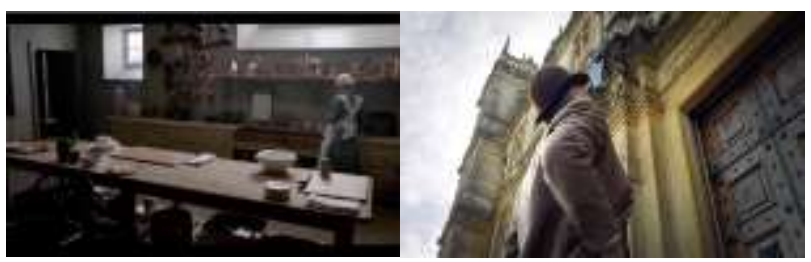

Fig. 3 Left figure: Servants' quarter's kitchen (Downton Abbey Ep 4 00:09:26). Right figure: Low-angle shot is used to signifies the object of the frame to be powerless (Downton Abbey Ep 2 00:29:51)

In brief, in Season 1 of Downton Abbey, the director adeptly used particular cinematographic elements and miseen-scenes to subtly communicate the social backgrounds of characters to the audience. Lighting, camera movements, camera shots, and even camera angles are carefully selected to showcase the wide social divides between the upper and lower classes of Edwardian England. The upper-class's position as the "leisure-class" and the lower-class people as the "working class" is underscored repeatedly by the director's choice of distinct camera movements, long or close-up shots, and lighting distinctions.

\section{B. Characterization}

The characterization is undeniably the most crucial element of a play, film, or TV series. It is the set of characters who presents and communicates the intended plot and its themes to the audience. In Downton Abbey, director Jullian Fellowes showcases significant subjects such as gender and socio-economic disparities through a narrative set in the Edwardian era, when the social discrimination between classes was palpably clear and explicitly expressed. Moreover, the limited social mobility possible at that time because of the stringently applied social hierarchy made it almost impossible for people to escape their working-class conditions. A person occupying the lower rungs of the social ladder was compelled to obey and respect the people who commanded superior social positions. The presence of servants in a house was the defining line between the middle and lower classes. Many middle-class families in the Edwardian era would prefer to abjure basic household needs so they could afford servants and maintain an illusion of wealth in their bid to command respect.

These class positions and the associated privileges are represented in Downton Abbey through the characters. The upper-class characters in Downton Abbey are never shown sullying their hands with any household work. It was the lot of servants to houseclean, prepare and serve lavish meals, and also look after all the personal needs of their masters. The participation of the upper-class characters was limited to the hosting of social events: inviting their friends and relations to dinners. The servants, of course, remained at the beck and call of their masters who would summon them using bells installed in every room. The bell symbolized the servant's never-ending chores: they should always make themselves available whenever and for whatever reason they were called.

The aristocratic Edwardian household applied strict rules for servants. All servers were expected to understand and adhere to these unspoken norms. First, no matter how close they were to their masters, their status as working-class aids would not change. Also, masters should never be allowed to hear the servants talking loudly; servants should never address their masters first; and they should avoid physical contact with their employers as much as possible. Further, the Edwardian household applied a strict hierarchy even for its servants. High-ranking and low-ranking servants were also stringently stratified. The highest-ranking servant was respected by other servants and even the masters; the lowestranking servant was treated as if invisible. Thus, in the Edwardian era, an individual was treated by others first a representative of a social class, and then a person.

Downton Abbey illustrates the value accorded to social position in the Edwardian era through its portrayal of the servants who work in Downton. In the hierarchy of the servants who worked in a household, the Butler was the highest-ranking server who headed the entire group of servants. All the servants in Downton regard the Butler, Mr. Carson (Jim Charter), as being almost as respectable as their masters. One of the ways in which Mr. Carson's high-rank is illustrated is through the gestures of the other servants. Whenever Mr. Carson enters the servants' dining hall, the other servants in the room stand up in a show of respect [Figure 4 (left)]. Notably, the servants perform this very same gesture when one of their masters enters the dining hall [Figure 4 (right)]. Significant attention is also given to the servants' seating arrangements, which was strictly observed in Edwardian country houses. The seating arrangements would themselves indicate a servant's rank: high-ranking servants would be seated closer to the Butler, while lowranking ones would be seated at appropriate distances according to their positions.

While the Butler, being the highest-ranking servant, was respected by all the servants, the lowest-ranked servant in English country houses was often treated disrespectfully. The lowliest menials in Edwardian households comprised mainly girls or boys between the ages of 13 and 15, the schoolleaving age in Britain in the early 20th century. However, being the youngest retainer did not guarantee that the work was easier than the chores performed by the other, more specialized domestic helps. On the contrary, the lowestranking servants were often obligated to stay outside the sight of the masters, as it was considered inappropriate for the masters to see them in the upstairs area. This almost unsurmountable chasm between the lowest-ranked servants and the aristocratic family ensured almost certain nameless, 
faceless invisibility for the youngest and most downtrodden of the servants as far as their masters were concerned.

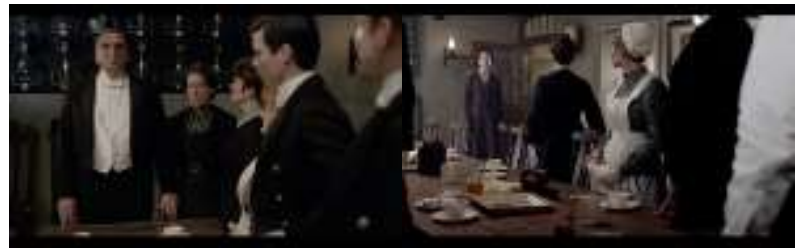

Fig. 4. Left figure: Other servants stand up if the Butler enter the dining hall (Downton Abbey Ep 4 00:26:55). Right figure: Servants stand up from their chair if the Master enters the dining hall (Downton Abbey Ep 2 00:18:10)

Daisy (Sophie McSera) the kitchen maid is the lowliest menial worker in Downton Abbey. Every morning, she is the first to wake up, and she rouses the other female servants before helping the housemaids clean the entire house. Daisy must also stay out of her masters' sights. For instance, when Daisy is cleaning the fireplace in the salon in Downton in Episode 1, Mrs. Hughes (Phyllis Logan), the housekeeper, tells her to finish up quickly. Mrs. Hughes is afraid that the family will see Daisy before she returns downstairs. Daisy is treated as if she does not matter. In one conversation, Mrs. Hughes tells her to finish her work quickly before anyone sees her. However, the term "anyone" in this context references only the masters of Downton because four other servants are visible in the scene. The contradiction between what is said and what is shown by the camera underscores Daisy's position as the lowly domestic aide who must not be seen or heard by her employers (Figure 5)

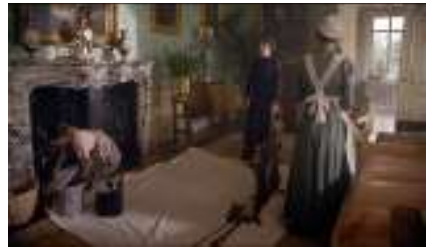

Fig. 5. Daisy cleaning the fireplace in Downton's salon (Downton Abbey Ep 100.04 .35$)$

A servant such as Daisy would perform two fundamental duties: she would serve the family, and she would help the other servants in the performance of their chores. Daisy's social standing is so low that it is deemed inappropriate for the masters to see her. In some country houses, the masters did not even know the person employed as the lowestranking servant because it was the housekeeper's duty to find someone suitable for this negligible position. Such a situation is exemplified in Downton Abbey in Episode 1 when the Duke of Crowborough pays a visit to Downton. The servants are asked to welcome the Duke; Daisy, however, is expected by Mr. Carson to remain downstairs.

The class inequities were also made more complicated by the marked gender disparities that were abundantly applied in Edwardian England. Obviously, the issues of gender were compounded in the less literate lower echelons of society. Women who worked as domestic help had to be satisfied with lower wages than their male counterparts. Male servants were considered superior in position to female servants (Meldrum, 2000). While the masters rarely saw the housemaids, male servants such as footmen, butlers, and valets were meant to be seen to emphasize the aura of glamor and luxury of the house. The male servants were required to wear proper uniforms as their public appearance indicated the social status of their masters because their services were costly. In an Edwardian aristocrat country house, tasks such as carrying bags, opening the front door, and serving meals would be executed by trained male servants. It was considered inappropriate and disrespectful to have female servants performing these jobs, especially when the master's guests were served.

Women were, thus, undoubtedly the weaker sex and their lower positioning was not limited to the underprivileged classes. Upper-class women, although educated, were not allowed to inherit property. All their money and other assets were handed over to their husbands after marriage.

This period also saw the continuation of the women's movements for suffrage and other social changes. Historically homebound women had tasted some freedoms during the first world war and were not prepared to relinquish all their liberties again after the war. The women's suffrage movement finally resulted in the "Qualifications for Women" rights in 1918, which finally allowed women above 21 to become members of parliament, and women over 30 who met certain property-related criteria could vote.

Downton Abbey aptly displays these gender inequalities through its: the Earl of Grantham (Hugh Bonneville) does not have a son and hence, none of his children will become heirs to the Downton estate or succeed him as the next Earl. Lord Grantham's daughters often express their sadness about not being able to inherit Downton, especially the eldest, Lady Mary.

In one scene the Butler (Jim Carter) expresses his desire to allow Bates (Brendan Coyle), who has a limp, to take on the duties of a valet. Bates' condition renders him incapable of helping the male staff members serve dinner to Lord Grantham's guests. Bates' job then must be performed by the housemaid. This situation causes great stress to Mr. Carson, who fears that Downton's reputation would be at stake if Lord Grantham permitted a less-valued female servant to perform the job of serving guests (Episode 1, 00:47:0700:47:28).

ROBERT, EARL OF GRANTHAM: Cheer up, Carson. There are worse things happening in the world.

MR CARSON: Not worse than a maid serving a duke.

ROBERT, EARL OF GRANTHAM: So you're quite determined?

MR CARSON: It's a hard decision, Your Lordship, a very hard decision, but the honor of Downton is at stake.

(Transcript of Downton Abbey Season 1 Episode 1 00:47:07 - 00:47:28)

In brief, characterization plays an important role in Downton Abbey in illustrating the social inequalities of gender and class in the Edwardian era through the family that owns and inhabits Downton and the retainers that serve them and also reside in quarters specified for them in the country manor. The layered inequalities described in this section are depicted in the ways the characters interact with respect or disrespect with each other in accordance with their gender and class positioning in the Edwardian social hierarchy.

\section{The Architecture and Interior Design of Downton}

According to Ervin Goffman's dramaturgical perspective, this world is divided into two different stages: the front 
stage and the backstage [1]. The front stage refers to the visible platform or venue. The backstage represents locations that are invisible to audiences. During stage performances, front stage players become admired and desired by external spectators because they showcase their most attractive aspects. However, backstage reveals their true selves, including facets and acts they may want to hide from other people (Kien, 2015).

According to Goffman, the two different stages affect how individuals perform themselves in the world. A person's identity, manner, and behavior in society may depend on the stage on which they are performing. In applying Goffman's theory to Downton Abbey, the country house named Downton may also be divided into a front stage and backstage. The front stage is represented by the "upstairs" residences of the erstwhile aristocratic family; the backstage is embodied by the "downstairs" servants' quarters or the areas occupied by the domestic help.

Besides being the area where the family resides, the front stage also indicates the aspects of the venue made visible to guests. In an era when social standings determined social relations, the English country house was an important symbol of an aristocrat's standing. As an indicator of social status, the upstairs area of these country houses was, therefore, a strong statement of the owner's tastes, preferences, and allegiances [8].

During the Edwardian era, the interior design of a country house was considered to be an integral part of its architectural scheme. Paintings, sculptures, and other ornamentations were utilized to communicate the owner's cultural sophistication and knowledge of the arts to visitors. The decor of Downton is often underscored in Downton Abbey to inform the audience of the family's aristocratic status. Particularly highlighted are the portraits that adorn the walls of Downton. Since the beginning of the 16th century, portraits have been essential items for the decoration of noble residences [8]. For example, a majestic portrait of Charles I with M. de St Antoine by Anthony van Dyck, one of the most influential artists in the 17th century, is placed on the wall of Downton's dining hall. This painting serves the dual function of decorating the house and communicating the family's reputation, sophistication, wealth, and cultural superiority (Figure 6).

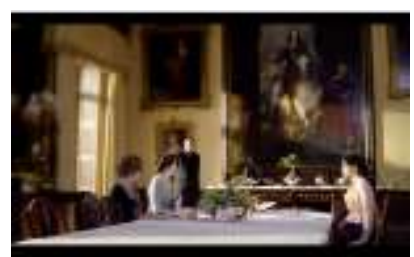

Fig. 6. Van Dyck's painting of Charles I with M. de St Antoine adorning the master's dining hall (Downton Abbey Ep 1 00:08:35)

In complete contrast, the architectural scheme and the interiors of the backstage or downstairs of Downton are bereft of luxurious trappings. Because it is invisible to guests, the downstairs premises are not considered important for the symbolization of the family's status. Downstairs only contains functional furniture and items for the basic use of the servants. Upstairs, the family dining area is adorned with beauty in the form of expensive portraits, vases, and other decorative ornaments; downstairs, the servants' dining room is simple, containing only a modest wooden dining table for 13 people, chairs, and kitchen equipment. The servant bell board is the only "decorative" item in the downstairs dining hall.

Also, the spacious upstairs bedrooms are filled with expensive furniture items that are suited to the aristocratic lifestyle (Figure 7); however, the downstairs bedrooms are small and simply styled, containing only functional items. Moreover, two or more servants would typically be required to share one small bedroom (Figure 8)

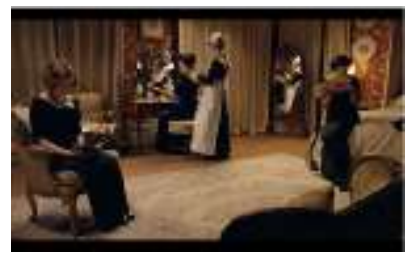

Fig. 7. Lady Mary’s bedroom (Downton Abbey Ep 1 00.29.15)

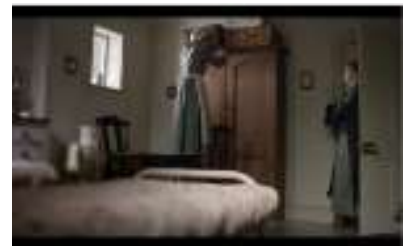

Fig. 8. Downton servants' bedroom (Downton Abbey Ep 3 00.01.21)

The boundaries between the front stage and backstage of Downton are, further, neatly demarcated. Most Edwardian country house owners insulated themselves from their servants as much as possible. Other than the division between upstairs and downstairs, servants were obligated to use different stairs so the masters could avoid their squalor and minimize physical proximity. Likewise, the servants in Downton used a separate staircase to traverse the distance between their downstairs and their masters' upstairs residences.

Similarly, the servants of a country house would use a different door to enter the house. Only the owner's family members, peers, guests were allowed to enter the house using the front door. It was considered inappropriate for people of lower social status to knock on the front door. This practice is demonstrated in the first episode of Downton Abbey when the Duke of Crowborough visits Downton. After welcoming the Duke, the servants do not follow the family and guests into the house through the front door. Instead, they walk away and use Downton's rear entrance.

When it came to the female servants, the front stage and backstage perspective became even more complex. As mentioned above, the female servants were placed lower in the hierarchy than their male counterparts. While male servants could demonstrate the wealth of their masters in the upstairs area, most female servants barring the housekeeper and lady's maid were expected to remain downstairs if they were not needed. The master's guests were almost exclusively served by the male servants. Therefore, the female servants remained relegated to the invisibility and the plain and tight environment of the downstairs. 
In brief, although both classes lived under the same roof, the masters and servants existed in entirely different "worlds" demarcated within the same premises. The differences between the front stage and the backstage of the houses represented the social chasm that existed between classes in the Edwardian era. In this period, the upper-class viewed the working class with disdain and tended to avoid physical contact through spatial separation. This division of space was even more pronounced for female servants, who were much less visible on the front stage than their male counterparts.

\section{CONCLUSION}

The above analysis has highlighted the manner in which the TV series Downton Abbey used characterization, miseen-scenes, and the architecture and interior design of its sets to represent the social values as well as the gender and class inequalities of Edwardian England. The characterization and the storyline of Downton Abbey are carefully constructed to accurately represent the gendered and stratified dimensions of the social order as accurately as possible. As the series depicts, Edwardian men commanded greater social and economic power while their women were not allowed to inherit property. In fact, the women belonging to the lower echelons of society were largely invisible to the masters whom they served. Men and women of the same class were also confined to their own social roles which were strictly regulated by rules of etiquette that were contextual to their space in society.

The cinematographic elements and the mise-enscenes of Downton Abbey are optimized to signify the social backgrounds of the characters. The director uses lots of camera movements and sounds in portraying the servants as if to emphasize their never-ending-chores. However, the camera tends to be stable and often uses long shots in scenes that show the aristocratic family to allow the audience to take in the lavish surroundings and the relaxed lifestyles of the aristocracy. The director also uses different lighting styles to depict the two distinct "stages" of the house. The low-key lighting of the servants' quarters and the bright lighting of the masters' areas underline the social contrasts between those who are showcased and those who should remain unseen.

Finally, the architecture and interior design of the country house, Downton, also emphasize the wide and unbridged gap between social classes in the Edwardian era. The stark distinctions between the upstairs front spaces and downstairs backrooms of Downton illustrate this wide chasm. In conclusion, the British TV series, Downton Abbey artfully and accurately portrays the gender and class inequities of Edwardian society through careful representations of characters, cinematography and mise-enscenes, as well as through the architecture and the interior design of Downton.

\section{REFERENCES}

[1] Goffman, E. (1978). The presentation of self in everyday life. Penguin Books: Harmondsworth.

[2] Broadwell, D., \& Thompson, K. (2005). Film art: An introduction (8th Edition). New York: McGraw-Hill.

[3] Rose, G. (2016). Visual methodologies: An introduction to researching with visual materials. London: SAGE Publications.

[4] Chaubel, C (2019). Class and the Domestic Service System through Downton Abbey. Universitat de Lleida Press.

[5] Helgadottir, O. (2014). The Edwardian era as Depicted in Downton Abbey. Iceland: University of Iceland Press.

[6] Baena, R \& Byker.,C (2014): Dialects of nostalgia: Downton Abbey and English identity, National Identities, DOI: 10.1080/14608944.2014.942262

[7] Mirzoeff, N. (2009) An Introduction to Visual Culture, 2nd edition. London: Routledge. Mirzoeff, N. (2011) The Right to Look: A Counterhistory of Visuality. Durham, NC: Duke University Press.

[8] Hynes, Samuel Lynn. The Edwardian Turn of Mind. Princeton, NJ: Princeton UP, 1968. Print.

[9] Stobart, Jon \& Rothery, Mark. Consumption and the Country House. Oxford : Oxford University Press, 2016 century. Oxford: Oxford University Press, 2017

[10] Feinberg, R. A., Mataro, L., \& Burroughs, W. J. (1992). Clothing and Social Identity. Clothing and Textiles Research Journal,11(1), 18-23. doi:10.1177/0887302x9201100103

[11] Fellowes, J \& Percival, B. (2010). Downton Abbey : Episode One. Gareth, United Kingdom: ITV Broadcasting.

[12] Fellowes, Julian. (2012) Downton Abbey. The Complete Scripts Season 1. New York: William Morrow. Print.

[13] Hall, S., Evans, J., \& Nixon, S. (1997). Representation: Cultural representations and signifying practises. Los Angeles, CA: Sage Publications.

[14] Girouard, M., Girouard, D., \& Dendy, W. (1992). Town and country:. New Haven: Yale University Press.

[15] Hobson, J. A., \& Veblen, T. (1994). Veblen: The theory of the leisure class. London: Routledge/Thoemmes Press.

[16] Maloney, A. (2011). Life below stairs: True lives of Edwardian servants. Leicester: Thorpe

[17] Kien. N (2015). Contenporary Social Interaction: How Communication Technologies Alter Goffman's Dramaturgical Model?. Ho Chi Minh City Open University Press.

[18] Meldrum, T. 2000. "Domestic service and gender, 1660-1750: Life and work in the London household". Harlow: Pearson Education. 